\title{
PENGARUH VARIASI SUSUNAN PIPA TERHADAP LAJU PELEPASAN KALOR PADA KOLEKTOR SURYA ABSORBER BATU GRANIT
}

\author{
Mirmanto ${ }^{1}$, Made Wirawan ${ }^{2 \star}$, Hendry Sakke Tira ${ }^{3}$ \\ 1,2,3 Jurusan Teknik Mesin Fakultas Teknik Universitas Mataram \\ JIn. Majapahit No.62 Mataram Nusa Tenggara Barat Kode Pos: 83125 \\ Telp. (0370) 636087; 636126; ext 128 Fax (0370) 636087 \\ *Email : wwiralo@yahoo.ac.id
}

\begin{abstract}
As the fossil energy gradually gets depletion, alternative energies should be utilized. One of alternative energies, which is easier to be used, is solar energy. In this research, the solar energy, which was captured using a flat plate collector with a granite absorber, was used to heat water. The overall dimension of the collector was 0,8 $m \times 1 m \times 0,01 \mathrm{~m}$ with a gap between the glas cover and the absorber of approximately $50 \mathrm{~mm}$. Copper pipes with a diameter of 1/2 inch were used to transfer the heat to the water. The volumetric rates of the water were $200 \mathrm{cc} /$ $\mathrm{min}, 250 \mathrm{cc} / \mathrm{min}$ and $300 \mathrm{cc} / \mathrm{min}$ and the water was flowed naturally from a higher water tank and was adjusted using a valve installed at the outlet of the collector.

The test results indicate that the energy absorbed by the water decreases with the observation time. The parallel pipes cause quick heat removals from the granite absorber. Energy absorbed by the water in the parallel pipes is much greater than that in the serpentine pipe, and the granite can be used for storing the heat energy
\end{abstract}

Keywords: solar collector, granite absorber, collector performance, heat removal rate.

\section{PENDAHULUAN}

Energi fosil di bumi sangat terbatas jumlahnya, sedangkan pertumbuhan penduduk dan perkembangan teknologi meningkat pesat. Hal ini menyebabkan penggunaan energi di muka bumi semakin bertambah sementara ketersediaan energi yang berupa energi fosil semakin menipis. Untuk mengatasi semakin berkurangnya energi ini maka beberapa upaya perlu dilakukan untuk mendapatkan sumber energi alternatif, salah satunya adalah energi surya atau energi matahari (Galuh, 2013 ).

Seiring dengan pertumbuhan penduduk, pengembangan wilayah, dan pembangunan dari tahun ke tahun, kebutuhan akan pemenuhan energi listrik dan juga bahan bakar secara nasional pun semakin besar. Maka tidak tertutup kemungkinan bahwa nantinya negara ini akan mengalami krisis energi. Maka dari itu dibutuhkan pola pikir para peneliti untuk mengembangkan potensi yang dimiliki matahari agar nantinya Indonesia tidak termasuk negara terkena dampak krisis energi global (Handjoko dan Hadi, 2011).

Ketersediaan energi surya dapat dikatakan tidak terbatas, terutama di negara tropis seperti Indonesia, dimana matahari bersinar sepanjang tahun. Pemanfaatan energi surya sebenarnya sejak dulu sudah dilakukan secara tradisional, tetapi sejalan dengan kemajuan teknologi, pemamfaatan energi surya telah berkembang pesat. Beberapa pemamfaatan teknologi surya yang telah dikembangkan diantaranya sebagai pemanas air, pemanas ruangan, alat pengering, dan sebagainya, Muharto dkk. (2011).

Energi yang datang ke bumi sebagian besar merupakan pancaran radiasi matahari. Energi ini kemudian ditransformasikan menjadi bermacam-macam bentuk energi, seperti pemanasan permukaan bumi, pemanasan atmosfer, fotosintesa tanaman dan reaksi fotokimia lainnya. Penyebaran sinar matahari setiap tahun dibelahan bumi bervariasi. Indonesia rata-rata menerima sinar matahari delapan jam perhari dan intensitas sinar matahari yang masuk ditentukan posisi matahari terhadap kolektor, Burhanuddin (2005).

Menurut Handjoko dan Hadi (2011), matahari adalah sumber energi tak terbatas dan sangat diharapkan dapat menjadi sumber energi pengganti yang sangat berpotensi. Kebutuhan energi di Indonesia masih dipenuhi dengan energi berbahan bakar minyak bumi dan batubara yang bersifat polutif dan tidak dapat diperbaharui. Sudia (2010) mengatakan bahwa energi matahari merupakan salah satu energi terbarukan yang memiliki potensi untuk dikelola dan dikembangkan khususnya pada daerah dengan intensitas radiasi matahari yang cukup tinggi. Untuk memanfaatkan energi 
matahari tersebut dibutuhkan suatu alat yang dikenal dengan kolektor surya yang salah satu manfaat kolektor surya ini adalah sebagai pemanas air. Sucipta dkk. (2010) menyatakan bahwa kolektor surya adalah salah satu teknologi pemanfaatan energi matahari, yang umumnya terdiri dari tiga bagian yaitu : pelat absorber berwarna gelap, pipa kalor dan penutup transparan dari kaca atau plastik. Kolektor surya dapat didefinisikan sebagai sistem perpindahan panas yang menghasilkan energi panas dengan memanfaatkan radiasi sinar matahari sebagai sumber energi utama. Ketika cahaya matahari menimpa absorber pada kolektor surya, sebagian cahaya akan dipantulkan kembali ke lingkungan, sedangkan sebagian besarnya akan diserap dan dikonversi menjadi energi panas. Energi panas tersebut dipindahkan kepada fluida yang bersikulasi didalam kolektor surya yang disebut dengan energi guna.

Kolektor yang digunakan pada penelitian ini adalah kolektor surya plat datar dengan absorber batu granit. Umumnya kolektor surya menggunakan absorber pelat logam sebagai penyerap panas sinar matahari. Namun pada penelitian ini penulis berkeinginan untuk mengetahui apakah batu granit dapat digunakan sebagai absorber. Jadi tujuan utama pada penelitian ini adalah tidak membandingkan kemampuan absorber logam dengan absorber batu granit, tetapi untuk mengetahui unjuk kerja absorber yang terbuat dari batu granit. Disamping itu, penelitian sebelumnya yang dilakukan Jatmiko (2014) yaitu membandingkan absorber batu granit dengan absorber pasir, menunjukan bahwa absorber batu granit lebih efisien dari pada absorber pasir. Bedanya penelitian ini dengan Jatmiko (2014) adalah (i) ukuran kolektor lebih besar (lebih mendekati ukuran pada pasaran) dan memakai variasi pipa yang berbeda. Pada penelitian yang dilakukan Jatmiko (2014), susunan pipa yang digunakan hanya berbentuk serpentine dan tidak meneliti susunan pipa paralel (lurus).

\section{LANDASAN TEORI Kolektor surya}

Menurut Alit dan Sutanto (2002), kolektor surya merupakan suatu peralatan penerima radiasi surya sekaligus merubahnya menjadi energi berbentuk panas, yang kemudian digunakan secara langsung maupun disimpan terlebih dahulu pada suatu unit penyimpanan panas. Sedangkan menurut Marbun (2009) kolektor surya merupakan suatu alat yang berfungsi untuk mengumpulkan energi matahari yang masuk dan diubah menjadi energi thermal atau energi guna.

Menurut Burhanuddin (2005) kolektor panas surya dibagi menjadi 4 macam, yaitu :

1. Kolektor surya plat datar

2. Kolektor terkonsentrasi

3. Kolektor tabung terevakuasi

4. Kolektor pasif

Tetapi pada penelitian ini yang menjadi obyek adalah kolektor plat datar, oleh sebab itu kolektor terkonsentrasi, kolektor tabung terevakuasi dan kolektor pasif tidak diuraikan lebih lanjut.Menurut Handjoko dan Hadi (2011), kolektor surya plat datar pada umumnya memiliki komponen-komponen utama, yaitu

1. Cover, berfungsi untuk mengurangi rugi panas secara konveksi menuju lingkungan.

2. Absorber, berfungsi untuk menyerap panas dari radiasi cahaya matahari.

3. Pipakalor, berfungsi sebagai pengambil panas dari absorber untuk digunakan sesuai keperluan.

4. Isolator, berfungsi meminimalisasi kehilangan panas secara konduksi dari absorber menuju lingkungan.

5. Frame, berfungsi sebagai struktur pembentuk dan penahan beban kolektor.

\section{Analisakesetimbangan energi pada kolektor surya plat datar}

Persamaan kesetimbangan energi panas pada kolektor termal plat datar dapat dinyatakan dengan persamaan:

$$
q_{u}=q_{i}-q_{l}
$$

Dimana :

$q_{u} \quad$ : energi yang guna $(\mathrm{W})$

$q_{i} \quad$ : energi yang masuk (W)

$q_{l} \quad$ : energi yang hilang (W)

Dari persamaandiatas dapat diketahui energi yang hilang kelingkungan atau kerugian energi dari kolektor plat datar tersebut.Energi panas masuk dapat dihitungberdasarkan pengukuran intensitas radiasi matahari dikalikan dengan luasan absorber. Hanya saja pada penelitian ini yang menjadi fokus adalah laju energi yang dilepaskan oleh kolektor ke air yang mengalir dalam pipa dan ke lingkungan dan qpukan lagi energi masuk tetapi merupakan energi tersimpan.

\section{Laju pelepasan energi panas Konduksi}

Panas mengalir secara konduksi dari daerah yang bertemperatur tinggi ke daerah yang bertemperatur rendah. Laju perpindahan panas konduksi dapat dinyatakan dengan 
hukum Fourier yang ditulis pada persamaan, Arismunandar (1985) :

Dimana :

$$
Q_{k}=-k A(d T / d x)
$$

$Q_{k} \quad$ :perpindahan panas konduksi $(\mathrm{W})$.

$k$ : konduktifitas termal $(\mathrm{W} / \mathrm{m} \mathrm{K})$.

$A$ : luas perpindahan panas $\left(\mathrm{m}^{2}\right)$.

$d t / d x:$ gradien temperatur dalam arah aliran panas $(\mathrm{K} / \mathrm{m})$.

Tanda minus (-) pada persamaan diatas tersebut menunjukkan bahwa kalor mengalami perpindahan dari temperatur tinggi menuju ke temperatur yang lebih rendah, Holman (1998). Kerugian panas konduksi pada kolektor ini terjadi pada luasan di bawah absorber dan ke empat dindingnya.

\section{Konveksi}

Perpindahan panas secara konveksi ini terjadi pada bagian atas penutup kolektor yang bersinggungan dengan udara luar dan di dalam ruang antara absorber dan penutup kolektor. Untuk perpindahan panas konveksi pada bagian atas penutup, dapat dihitung berdasarkan perbedaan suhu penutup kolektor sebelah luar dengan suhu lingkungan. Sedangkan perpindahan panas di dalam ruang diantara absorber dan penutup kolektor dapat dihitung berdasarkan perbedaan suhu absorber dengan suhu udara di atasnya dan perbedaan suhu udara di bawah penutup dengan suhu penutup permukaan bawah. Namun karena suhu di permukaan sebelah bawah penutup kolektor tidak diukur, maka akan sulit untuk dilakukan perhitungan. Tetapi kalor yang mengalir dari absorber melalui udara diantara absorber dan penutup kolektor pada hakekatnya sama dengan laju kalor konveksi dari permukaan atas penutup kolektor ke lingkungan. Untuk itu kerugian konveksi dari permukaan atas penutup kolektor ke lingkungan dapat diprediksi dengan persamaan, Holman (1998):

Dimana :

$$
Q_{C}=h_{c} A_{c}\left(T_{w a}-T_{f}\right)
$$

$Q_{C}$ : perpindahan panas konveksi $(\mathrm{W})$.

$h_{c}$ : koefisien konveksi $\left(\mathrm{W} / \mathrm{m}^{2} \mathrm{~K}\right)$.

$A_{c}$ : luas permukaan absorber kolektor surya $\left(\mathrm{m}^{2}\right)$.

$T_{w a}$ : temperatur dinding bagian atas penutup kolektor $(\mathrm{K})$.

$T_{f}$ : temperatur fluida $(\mathrm{K})$.

\section{Radiasi}

Perpindahan panas radiasi benda hitam yang sempurna sebanding dengan pangkat empat dari temperatur benda tersebut. Ini merupakan hokum Stefan-Boltzmann yang dapat dituliskan sebagai berikut (Beiser, 1981; Holman, 1988):

$$
Q_{r}=\tau \sigma A\left(T_{a b}^{4}-T_{\infty}^{4}\right)
$$

Dimana :

$Q_{r}$ : perpindahan panas radiasi $(\mathrm{W})$.

$\sigma \quad$ : konstanta Stefan-Boltzmann $\left(\mathrm{W} / \mathrm{m}^{2}\right.$ $\mathrm{K}^{4}$ ).

$A$ : luas permukaan $\left(\mathrm{m}^{2}\right)$.

$T_{a b}$ : temperatur absorber $(\mathrm{K})$.

$T_{\infty}$ : temperatur lingkungan $(\mathrm{K})$.

$T \quad$ : transmisivitas penutup kolektor.

\section{Rugi-rugi kalor yang terjadi}

Kerugian panas secara keseluruhan adalah kerugian panas yang terdiri dari kerugian kalor ke atas, ke bawah dan ke samping, dimana kerugian panas ini dapat terjadi secara konduksi, konveksi dan radiasi seperti ditunjukan pada persamaan, (Holman, 1988):

$Q_{L}=Q_{A}+Q_{B}+Q_{S}$

Dengan $Q_{L}$ menyatakan kerugian panas secara keseluruhan (Watt), $Q_{A}$ menyatakan kerugian panas bagian atas (Watt), $Q_{b}$ menyatakan kerugian panas ke bawah (Watt), dan $Q_{S}$ menyatakan kerugian panas dari samping kolektor (Watt).

Radiasi matahari yang mengenai permukaan kolektor, sebagian besar akan diserap dan dihantarkan ke fluida yang disebut dengan energi guna. Namun demikian juga terdapat kerugian energi dari kolektor ke lingkungan akibat adanya perbedaan suhu.

Kerugian kalor ini dapat dianalisis sebagai berikut:

1. Kerugian kalor atas

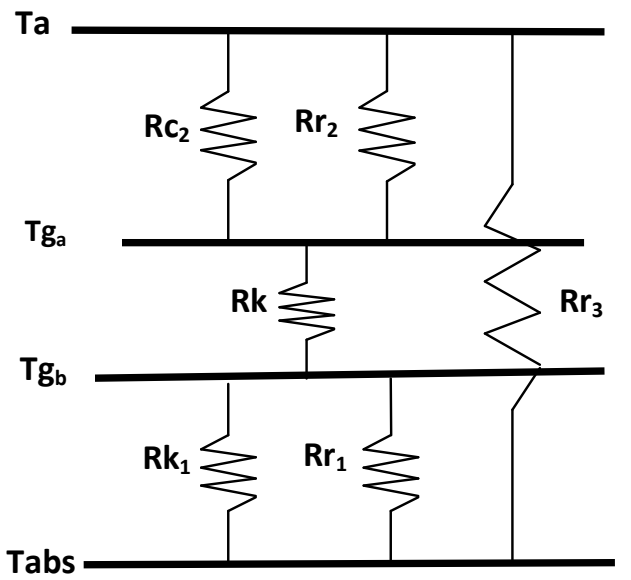

Gambar 2.1. Rangkaian termal untuk kerugian kalor bagian atas secara keseluruhan.

Kerugian kalor pada bagian atas adalah hilangnya kalor dari kolektor ke lingkungan 
pada bagian atas kolektor, ini dapat dirumuskan sebagai berikut,Holman (1998):

$$
Q_{a}=\frac{T_{a b s}-T_{a}}{R_{t}}
$$

dimana $T_{\text {abs }}$ menyatakan temperatur absorber (K), $T_{a}$ menyatakan temperature lingkungan (K) dan nilai $R_{\text {total }}$ dapat dicari dari persamaan berikut, Holman (1998):

$>$ Perhitungan nilai resistan konveksi $\left(R c_{2}\right)$ antara kaca ke lingkungan

$$
R_{c 2}=\frac{1}{h \times A_{g}}
$$

$>$ Perhitungan nilai resistan radiasi $\left(R r_{2}\right)$ antara kaca kelingkungan

$$
R_{r 2}=\frac{1}{F_{r} \times \sigma \times A_{g} \times\left(T_{g}+T_{a}\right)\left(T_{g}{ }^{2}+T_{a}{ }^{2}\right)}
$$

Perhitungan nilai resistan konduksi $\left(R k_{1}\right)$ antara absorber ke kaca

$$
R_{k 1}=\frac{\Delta x}{K_{u d a r a} \times A_{a b s}}
$$

Perhitungan nilai resistan radiasi $\left(R r_{1}\right)$ antara absorber ke kaca

$R_{r 1}=\frac{1}{F_{r} \times \sigma \times A_{a b s} \times\left(T_{a b s}+T_{g b}\right)\left(T_{a b s}{ }^{2}+T_{g b}{ }^{2}\right)}$

Perhitungan nilai resistan konduksi $\left(R_{k}\right)$

$$
R_{k}=\frac{\Delta x}{K_{g} \times A_{g}}
$$

Perhitungan nilai resistan radiasi $\left(R r_{3}\right)$ antara absorber ke lingkungan

$$
R_{r 3}=\frac{1}{F_{r} \times \sigma \times \tau \times A_{c} \times\left(T_{a b s}+T_{a}\right)\left(T_{a b s}^{2}+T_{a}^{2}\right)}
$$

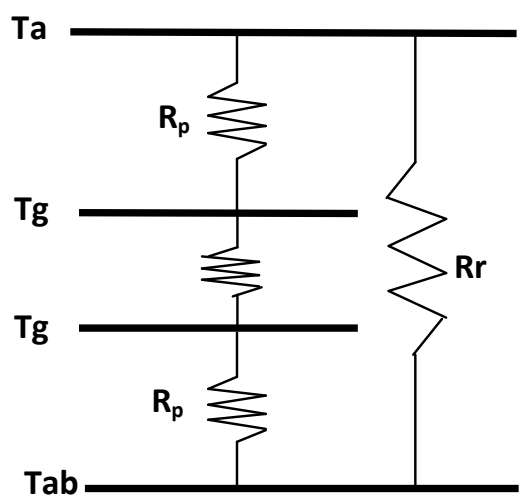

Gambar 2.2. Rangkaian termal paralel untuk kerugian kalor bagian atas

Rangkaian pararel $\left(R p_{2}\right)$ dan nilai kalornya

$$
R_{p 2}=\frac{R_{c 2} \times R_{p 2}}{R_{c 2}+R_{p 2}}
$$

Rangkaian pararel $\left(R p_{1}\right)$ adalah

$$
R_{p 1}=\frac{R_{k 1} \times R_{p 1}}{R_{k 1}+R_{p 1}}
$$

Ta

Tabs

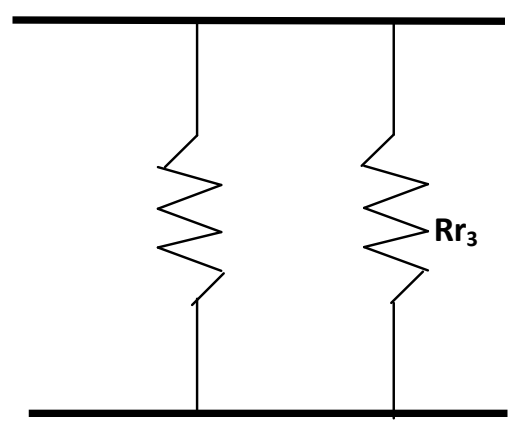

Gambar 2.3. Rangkaian termal untuk kerugian kalor bagian atas setelah $R_{p 2}, R_{k}$ dan $R_{p 1}$ diserikan.

Rangkaian seri $\left(R s_{1}\right)$

$R_{s 1}=R_{p 1}+R_{p 2}+R_{k}$

$>$ Maka Rangakain total $\left(R_{\text {total }}\right)$

$$
R_{\text {total }}=\frac{R_{s 1} \times R_{r 3}}{R_{s 1}+R_{r 3}}
$$

dimana, $A_{a b s}$ menyatakan luasan absorber $\left(\mathrm{m}^{2}\right), \quad A_{g}$ menyatakan luasan kaca, $A_{c}$ menyatakan luasan kolektor, $\mathrm{Fr}$ menyatakan faktor bentuk. , $\tau$. menyatakan transimivitastas dari kaca penutup, $\sigma$ menyatakan konstantan Stefan-Boltzmann $\left(\mathrm{W} / \mathrm{m}^{2} \mathrm{~K}^{4}\right)$ dan $T_{a b s}$ menyatakan temperatur absorber (K), $T_{a}$ menyatakan temperatur lingkungan (K), $k$ menyatakan konduktivitas $(\mathrm{W} / \mathrm{m} \mathrm{K}), \Delta x$ menyatakan tebal dari material. 
2. Kerugian kalor ke bawah

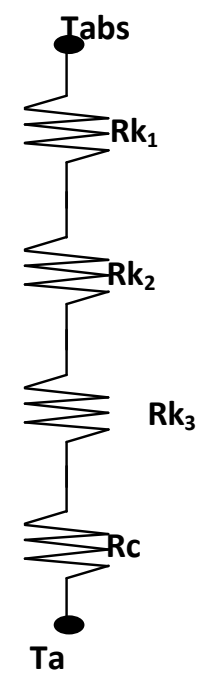

Gambar 2.4. Rangkaian termal untuk kerugian kalor bagian bawah.

Pada gambar 2.4, tahanan termal diatas adalah menggambarkan aliran energi yang hilang dibagian bawah yang dapat terjadi secara konduksi dan konveksi. Secara konduksi yaitu peprindahan panas yang terjadi dari permukaan atas absorber ke permukaan luar dinding (kayu) dan secara konveksi terjadi perpindahan kalor dari dinding permukaan luar kayu ke lingkungan. Berikut adalah persamaan yang merumuskan kerugian kalor bagian bawah secara langsung menyeluruh (Holman, 1988):

$$
Q_{B}=\frac{\left(T_{a b s}-T_{a}\right)}{R_{\text {total }}}
$$

Dimana $R_{\text {tota }}$ dapat dicari dari persamaan-persamaan berikut (Holman, 1988):

$>$ Nilai $R$ konduksi untuk absorber

$$
R_{k 1}=\frac{\Delta x_{a b s}}{K_{a b s} \times A_{a b s}}
$$

Nilai $R$ konduksi untuk isolasi atau sterofoam

$$
R_{k 2}=\frac{\Delta x_{\text {isolasi }}}{K_{\text {isolasi }} \times A_{\text {isolasi }}}
$$

Nilai $R$ konduksi untuk triplek

$$
R_{k 2}=\frac{\Delta x_{\text {triplek }}}{K_{\text {triplek }} \times A_{\text {triplek }}}
$$

Nilai $R$ konveksi
Nilai $R_{\text {total }}$

$$
R_{c}=\frac{1}{h \times A_{\text {triplek }}}
$$

$$
R_{\text {total }}=R_{k 1}+R_{k 2}+R_{k 3}+R_{c}
$$

3. Kerugian kalor ke samping

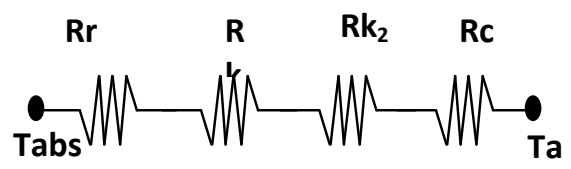

Gambar 2.5. Rangkaian termal untuk kerugian kalor bagian samping.

Kerugian kalor bagian samping dapat dirumuskan dengan persamaan dibawah ini, Holman (1998) :

$$
Q_{s}=\frac{\left(T_{a b s}-T_{a}\right)}{R_{\text {total }}}
$$

dimana $R_{\text {total }}$ dapat dicari dengan persamaan sebagai berikut:

> Nilai resistan radiasi untuk kerugian kalor samping dari absorber ke dinding isolasi :

$$
R_{r}=\frac{1}{\sigma \times A_{c, \text { samping }} \times\left(T_{a b s}+T_{w d}\right)\left({T_{a b s}}^{2}+{T_{w d}}^{2}\right)}
$$

$>$ Nilai resistan konduksi untuk isolasi atau sterofoam adalah :

$$
R_{k 1}=\frac{\Delta x_{\text {isolasi }}}{K_{\text {isolasi }} \times A_{\text {isolasi }}}
$$

Nilai resistan konduksi untuk kayu :

$$
R_{k 2}=\frac{\Delta x_{\text {kayu }}}{K_{\text {kayu }} \times A_{\text {kayu }}}
$$

Nilai resistan konveksi dari samping :

$$
R_{c}=\frac{1}{h \times A_{\text {kayu }}}
$$

Maka resistan total :

$$
R_{\text {total }}=R_{r}+R_{k 1}+R_{k 2}+R_{c}
$$

\section{Efisiensi kolektor}

Kolektor surya memiliki effisiensi panas yang berguna, efisiensi panas yang berguna pada kolektor surya dapat dicari dengan persamaan dibawah ini :

$$
\eta=\frac{Q_{u}}{Q_{i n}} \times 100 \%
$$


dimana $\eta$ adalah efisiensi panas yang berguna (\%)

\section{METODE PENELITIAN}

Metode yang digunakan pada penelitian ini adalah eksperimen langsung di lapangan dengan menggunakan prototipe (model) alat eksperimen guna memperoleh variabel yang diinginkan. Sedangkan penelusuran literatur digunakan untuk menyusun pendahuluan, tinjauan pustaka dan dasar teori.

\section{Tempat penelitian}

Penelitian dilakukan di lapangan di Jalan Merdeka 17 BTN Pagesangan pada bulan Agustus 2014 sampai Oktober 2014.

\section{ANALISA DATA DAN PEMBAHASAN}

Untuk mengidentifikasi kalor yang diserap oleh air pada kolektor surya pada debit $200 \mathrm{cc} / \mathrm{min}, 250 \mathrm{cc} / \mathrm{min}$ dan $300 \mathrm{cc} / \mathrm{min}$ maka gambar 4.1 menyajikan hubungan antara kenaikan temperatur air terhadap jam pengamatan untuk jumlah pipa yang berbeda

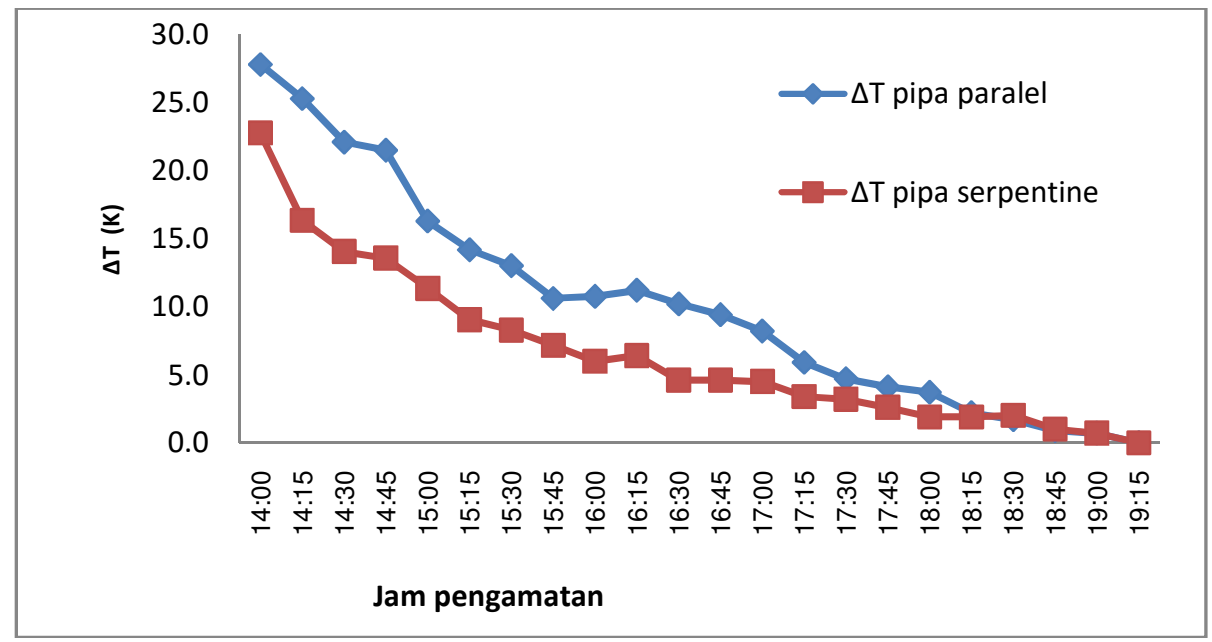

Gambar 4.1. Hubungan kenaikan temperatur air $(\Delta T)$ untuk pipa parallel dan pipa serpentine terhadap jam pengamatan.

Dari gambar 4.1 terlihat bahwa $\Delta T$ menurun baik untuk absorber dengan pipa parallel maupun pipa serpentine seiring bertambahnya jam pengamatan. Hal ini dikarenakan pada pukul 14.30 wita dan sesudahnya, itensitas radiasi matahari mulai berkurang bahkan dapat mencapai nol setelah sekitar jam 18.00 Wita, sehingga kalor yang diterima oleh masing-masing kolektor pun semakin kecil.

Hubungan antara kalor yang digunakan (Quse) untuk pipa parallel dan pipa serpentine pada debit yang sama terhadap jam pengamatan dapat dilihat pada gambar 4.2.

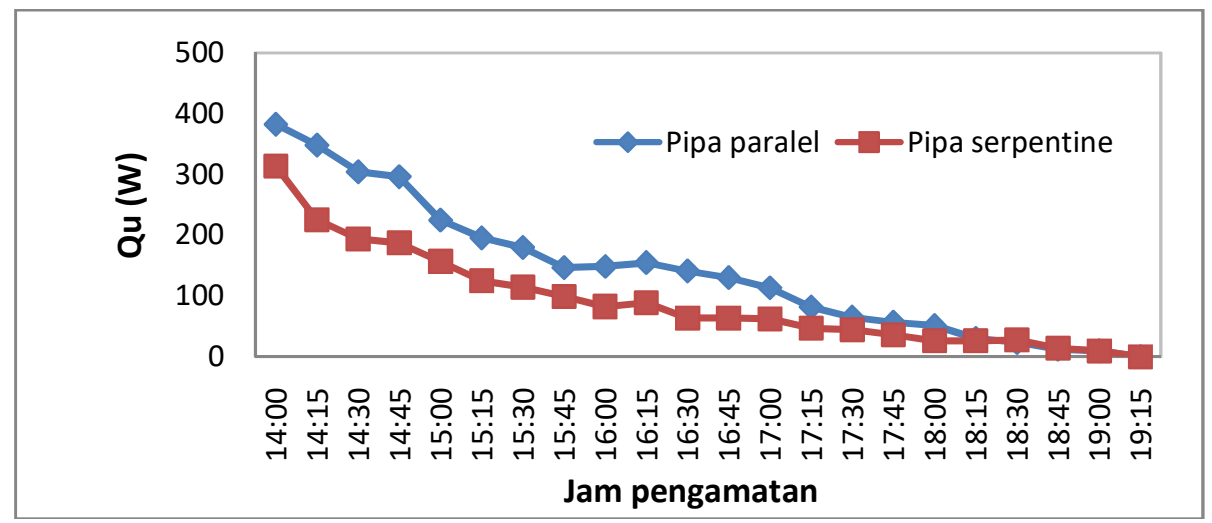

Gambar 4.2. Hubungan kalor yang diserap air (Qu) antara pipa serpentine dan pipa parallel terhadap jam pengamatan. 
Dari gambar 4.2 terlihat bahwa $Q_{u}$ atau energy guna menurun baik di pipa parallel maupun pipa serpentine seiring bertambahnya jam pengamatan. Setelah radiasi matahari tidak ada yang masuk kekolektor atau lewat jam 18.00 Wita,air pada kolektor surya absorber batu granit pipa paralel dan pipa serpentine tersebut ternyata masih mengalami kenaikan suhu atau suhu air keluar masih lebih tinggi dari pada suhu air masuk. Ini berarti bahwa air hanya menyerap kalor yang masih tersimpan di dalam batu granit dan sekaligus membuktikan bahwa batu granit dapat menyimpan kalor. Dari gambar 4.2 besar kalor yang digunakan oleh pipa parallel lebih besar dari pipa serpentine. Kolektor surya pipa parallel lebih banyak menyerap panas dibandingkan pipa serpentine, ini terjadi karena variasi bentuk susunan pipa yang berbeda dimana pipa parallel memiliki percabangan sehingga aliran air terbagi sesuai dengan jumlah percabangan pipa yang menyebabkan penyerapan panas dari pipa akan semakin besar dari pada pipa serpentine yang hanya satualiran. Artinya semakin banyak percabangan atau pembagian aliran air maka proses pemanasan air atau penyerapan panas akan semakin besar yang menyebabkan temperature keluar air semakin tinggi.

Hubungan antara suhu absorber terhadap jam pengamatan disajikan pada gambar 4.3. Suhu absorber menurun seiring dengan bertambahnya jam pengamatan. Hal ini disebabkan karena semakin sore, radiasi matahari yang diterima absorber semakin berkurang. Kalor yang digunakan untuk memanaskan air pun juga turun dengan bertambahnya jam pengamatan. Perbandingan temperatur absorber dengan variasi bentuk pipa, terlihat bahwa pipaserpentine memiliki nilai temperatur absorber lebih besar dibandingkan dengan pipa parallel untuk sebelum jam 16.00 Wita. Setelah lewat jam 16.00 Wita, kurang lebihnya suhu absorber dari kedua bentuk sama atau tidak siknifikan perbedaannya.

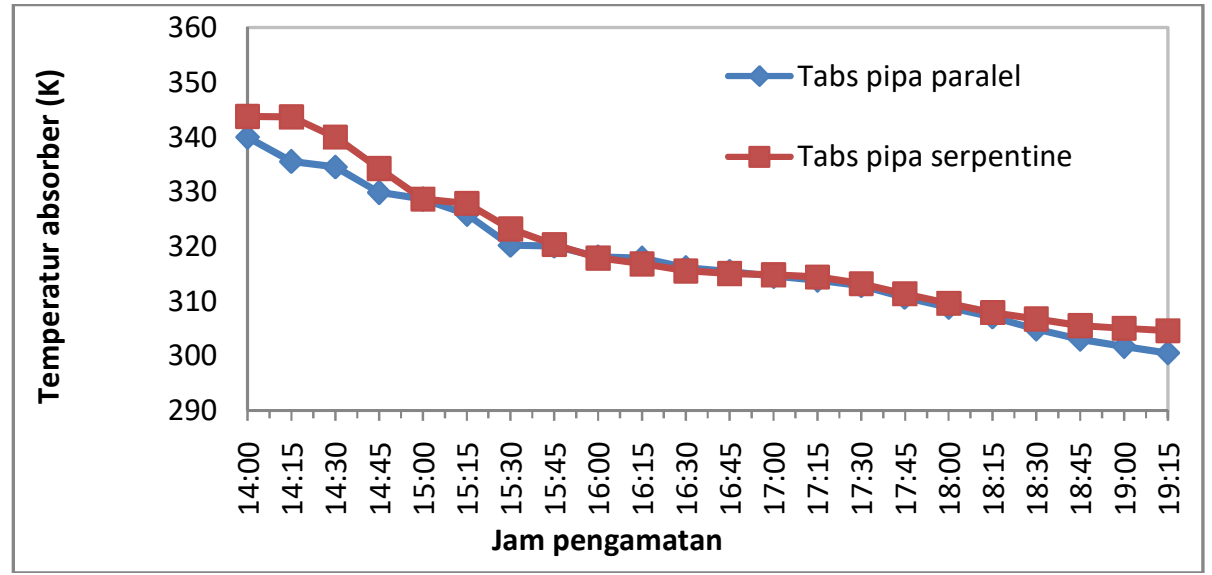

Gambar 4.3. Hubungan suhu absorber (Tabs) untuk pipa parallel dan pipa serpentine terhadap jam pengamatan.

Hubungan antara suhu air keluar dengan jam pengamatan untuk absorber dengan variasi bentuk pipa parallel dan bentuk serpentin ditunjukan pada gambar 4.4. Dari gambar 4.4 terlihat bahwa temperatur air keluar pada pipa parallel lebih tinggi dari pada pipa serpentine, hal ini disebabkan karena bentuk variasi susunan pipa yang berbeda yang memiliki percabangan yang mengakibatkan air akan menyerap panas lebih besar karena terbagi menjadi beberapa aliran sesuai dengan percabangan sehingga temperatur air keluar akan lebih tinggi seperti yang terlihat pada gambar 4.4. dan pembahasan gambar 4.2. 


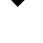

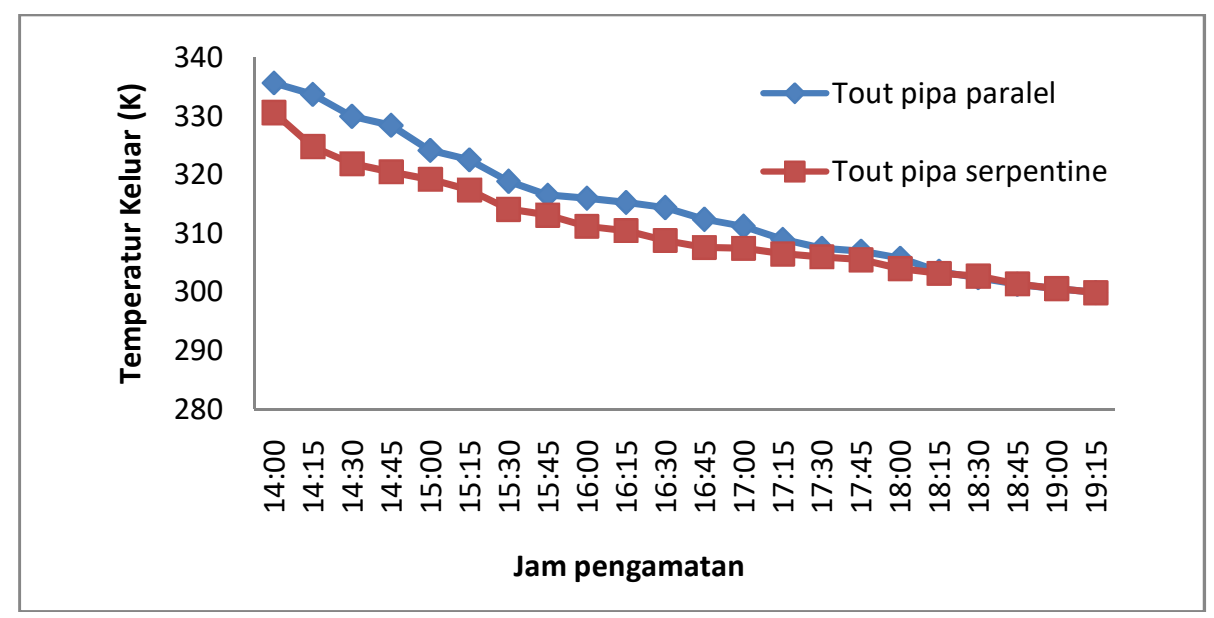

Gambar 4.4 Hubungan suhu keluar dengan kerugian kalor untuk pipa parallel dan pipa serpentine terhadap jam pengamatan.

Hubungan antara kerugian kalor jam pengamatan dapat dilihat pada gambar (Qloss) untuk pipa parallel dan pipa 4.5. serpentine pada debit yang sama terhadap

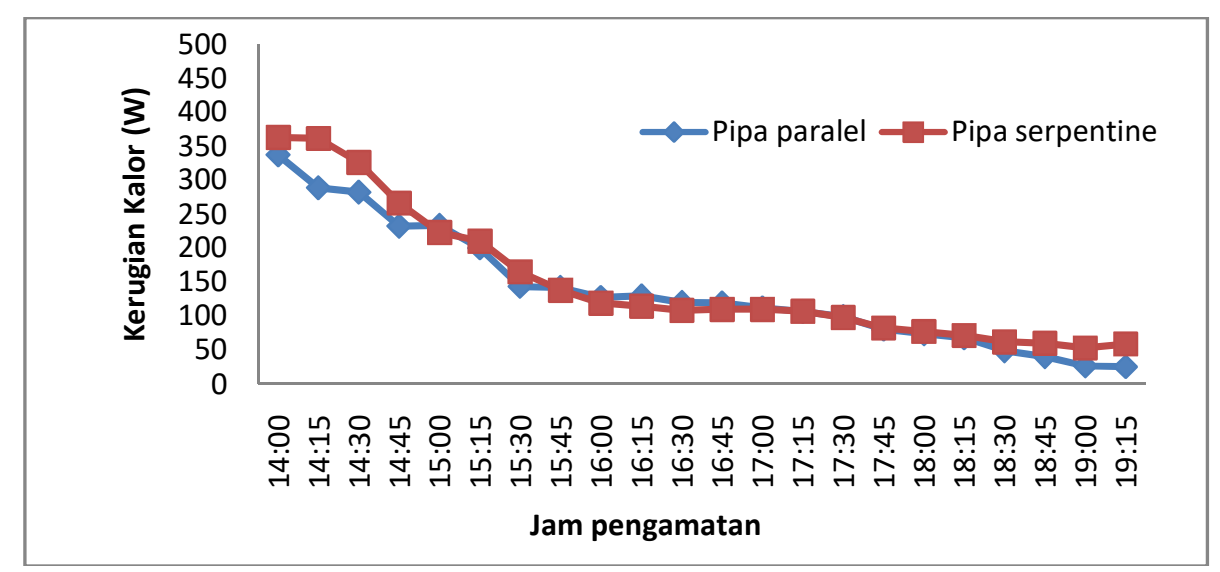

Gambar 4.5. Hubungan kerugian kalor (Qloss) untuk pipa parallel dan pipa serpentine terhadap jam pengamatan.

Dari gambar 4.5 telihat bahwa kerugian kalor menurun seiring dengan makin bertambahnya jam pengamatan. Hal ini disebabkan karena semakin sore suhu absorber semakin turun sedangkan kerugian kalor merupakan fungsi dari suhu absorber. Suhu absorber tinggi kerugian juga tinggi dan jika suhu absorber rendah, kerugian juga rendah, lihatlah persamaan kerugian kalor di halaman sebelumnya. Dari gambar $4.5 \mathrm{di}$ atas terlihat bahwa pipa serpentine memiliki kerugian kalor yang lebih banyak dari pada pipa paralel, hal ini disebabkan karena proses perpindahan panas pada pipa serpentin kurang baik.

\section{KESIMPULAN}

Berdasarkan hasil penelitian analisa data dan pembahasan dapat ditarik kesimpulan sebagai berikut:

1. Variasi bentuk pipa berpengaruh terhadap laju perpindahan panas pada kolektor.

2. Laju perpindahan kalor pada pipa paralel (pipalurus) lebih besar daripada pipa serpentine (berliku).

3. Variasi bentuk pipa mempengaruhi suhu air keluar, energy guna dan efisiensi kolektor.

4. Variasi bentuk pipa mempengaruhi besar kecilnya kerugian energy kelingkungan. 
5. Bentuk pipa-pipaparalel mempercepat pengambilan panas dari absorber batu granit.

\section{DAFTAR PUSTAKA}

Alit, I.B. dan Sutanto, R., 2002, Rancang Bangun Kolektor Tubular yang Memanfaatkan Lampu Neon Bekas Sebagai Kaca Penutup Kolektor, Jurnal Teknologi Industri, Vol VI No. 4, Oktober 2002, 225234.

Arismunandar, W., 1995, Teknologi Rekayasa Surya, PT. Pratnya Paramita, Jakarta.

Beiser, A., 1995, Concept of Modern Physics, $5^{\text {th }}$ edition, Mc Grow Hill, New York.

Burhanuddin, A., 2005 ; Karakteristik Kolektor Surya Plat Datar Dengan Variasi Jarak Penutup Dan Sudut Kemiringan Kolektor, Jurusan Fisika, UNS, Surabaya

Holman, J.P., 1988 ; Perpindahan Kalor, Penerbit Erlangga, Jakarta.

Jatmiko, H., 2013; Kajian Eksperimental Penggunaan Absorber Pasir Dan Absorber Batu Granit Terhadap Laju
Perpindahan Kalor Yang diterima Air Pada Kolektor Surya Tipe Plat Datar, Tugas Akhir, Universitas MataramMataram

Marbun, N.M, 2009 ; Rancang Bangun Sebuah Pemanas Air Tenaga Surya Dengan Menggunakan Kolektor Surya Plat Datar, Tugas Akhir, Universitas Sumatera Utara. Medan.

Muharto, A., Ana, D., dan Veny,I., 2011 ; Efektivitas Penyerapan Panas Sinar Matahari Oleh Air Yang Mengalir Dalam Pipa, JurusanTeknik Kimia, Surabaya.

Sucipta, M., Suardamana, I M dan Astawa, K., 2010 ; Analisis Performa Kolektor Surya Pelat Bersirip Dengan Variasi Luasan Permukaan Sirip, Jurnal IlmiahTeknik Mesin Cakram, Vol 4 No 2,Oktober 88-92. UniversitasUdayanan. Jimbaran-Bali.

Sudia, B., 2010 ; Unjuk Kerja Kolektor Surya Plat Datar Menggunakan Konsentrator Dua Cermin Datar, Teknik Mesin Fakultas Teknik Universitas Haluoleo, Kendari. 